Japan. J. Med. Sci. Biol., 25, 281-285, 1972

\title{
NOTES
}

\section{STANDARDIZATION OF TETANUS TOXOID COMBINED WITH PERTUSSIS VACCINE}

\author{
II. SOME CONSIDERATIONS ON THE STANDARD TOXOID \\ FOR THE ASSAY OF COMBINED VACCINE
}

\begin{abstract}
Murata, Someya and Kaneko (1970) showed that the responses of children to tetanus toxoid combined with pertussis vaccine were parallel with the potency of the tetanus component while their responses to fluid tetanus toxoid of the equivalent potency were poor. Possible factors responsible for such discrepancies between animal potency and human responses were discussed and a suggestion was made that combined vaccine may be preferable to fluid toxoid as the standard for assay purpose. This. paper gives further evidences to prove that fluid toxoid is not suitable as the standard for the assay of the toxoid component of combined vaccine. In Japan, all the biological products are tested in duplicate by the manufacturers and the National Institute of Health, Tokyo (NIH). In the test of combined vaccine (PDT)* the duplicate assays. of ten gave significantly different potencies of the tetanus component. The potency of tetanus toxoid is usually determined by comparison with the National Standard Tetanus Toxoid, plain (called "standard toxoid") and expressed in international unit (IU). The standard toxoid is a lyophilized, partially purified tetanus toxoid. It is. usually distributed as a solution containing $30 \mathrm{IU} / \mathrm{ml}$ in $\mathrm{M} / 60$ phosphate buffer ( $\mathrm{pH}$ 7.2 ) added with $0.02 \%$ gelatin (called GPB hereafter)**. On 81 of 93 triple vaccines. (PDT) submitted to the NIH during 1967-1969, the duplicate potency tests of tetanus. component were performed. Significant differences in the potency were found on 10 . specimens $(12.3 \%)$; higher values were obtained always by the manufacturers. The responses of the immunized animals to the standard toxoid were very poor in the former laboratory, while those to the combined vaccine were comparable to each other, as illustrated in Fig. 1a. Sometimes, animal responses were greatly influenced by the diluent. As shown in Fig. 1b, the responses to the standard toxoid were poorer when the specimen was diluted with saline instead of GPB, while those to the combined vaccine were affected slightly by dilution in saline; the calculated potency was apparently higher when saline was used as the diluent. Such an effect of the diluent on the potency was different depending on the laboratories (see below).

Thus the animal responses to fluid toxoid and combined vaccine are influenced by various factors in different ways, therefore a significant difference in the potency is sometimes observed. In order to scrutinize further the responses of guinea pigs to. two types of tetanus toxoid, 3 toxoid preparations were tested in 8 laboratories in this country (see Annexe). In this experiment the standard toxoid was distributed in

\footnotetext{
* Abbreviations. P: Pertussis vaccine; D: Diphtheria toxoid;

T: Tetanus toxoid; Lab: Laboratory (used only for the name of the participants)

** Before 1971, the concentration of phosphate in GPB was $\mathrm{M} / 10$ instead of $\mathrm{M} / 60$.
} 

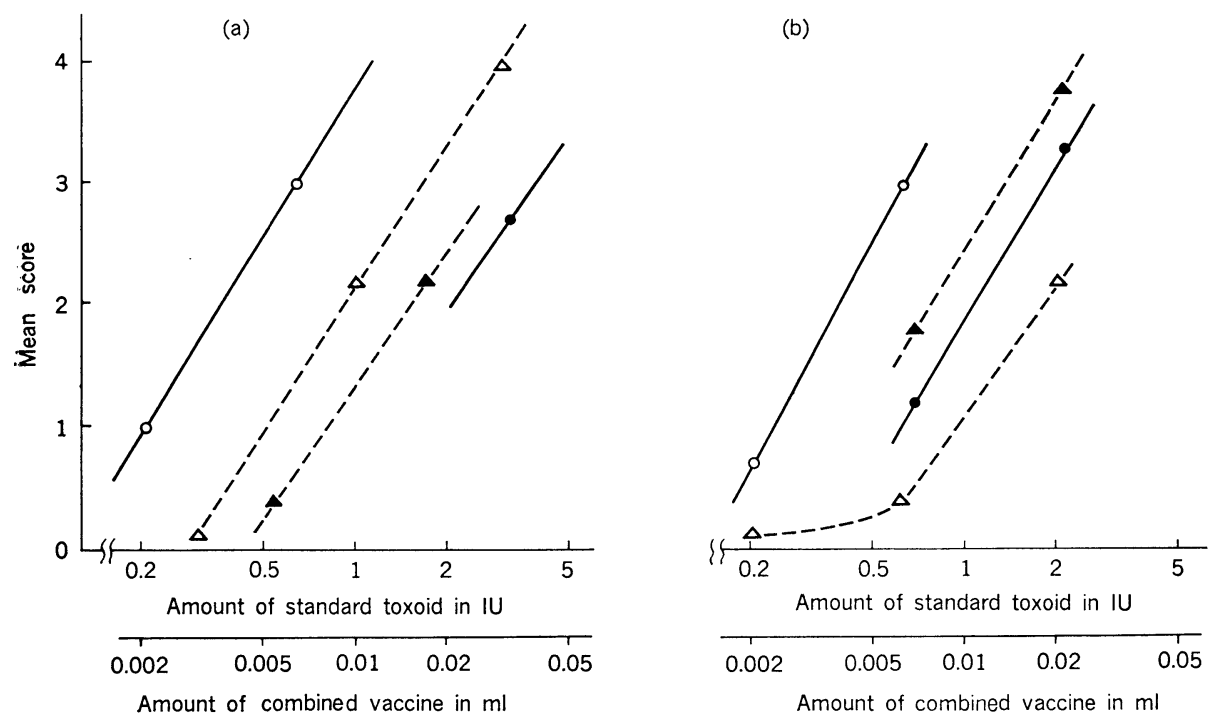

Fig. 1. Different animal responses to fluid tetanus toxoid and to combined vaccine (PDT).

(a) Shows the difference between two laboratories (NIH and Lab. II). The standard toxoid (ST) and a combined vaccine PDT-E24 produced in Laboratory II $\left(\mathrm{P} 24 \times 19^{9} / \mathrm{ml}, \mathrm{D} 56 \mathrm{Lf} / \mathrm{ml}\right.$, $\mathrm{T} 17 \mathrm{Lf} / \mathrm{ml}$ ) were diluted with GPB containing $\mathrm{M} / 10$ phosphate. Mean scores of ten guinea pigs were plotted: —O- NIH-ST, - - NIH PDT-E24, --- --- Lab. II-ST, - - - - - Lab. II-PDT-E24. Immunization period: 4 weeks. Challenge toxin: $20 \mathrm{LD}_{50}$. Calculated potencies of PDT-E24: $72 \mathrm{IU} / \mathrm{ml}$ and $17 \mathrm{IU} / \mathrm{ml}$ with the fiducial limits of 33$154 \mathrm{IU} / \mathrm{ml}$ and 8.7-31.5 IU/ml, respectively in Lab II and NIH.

(b) Shows the effect of diluent on the animal resposes: The standard toxoid and PDT 368 (see the text) were diluted with GPB containing M/10 phosphate (- $\mathrm{O}-\mathrm{ST}$, - PDT 368) or with saline (-- - - - ST, - - - - PDT 368). Other conditions: see (a). Calculated potencies of PDT 368: $319 \mathrm{IU} / \mathrm{ml}$ and $49 \mathrm{IU} / \mathrm{ml}$ with the fiducial limits of $227-446 \mathrm{IU} / \mathrm{ml}$ and $32-75 \mathrm{IU} / \mathrm{ml}$, respectively for saline and GPB groups.

a lyophilized state and diluted in each laboratory. A preparation of combined vaccine (PDT) was obtained from Dr. van Ramshorst of the Rijks Instituut voor de Volksgezondheid of the Netherlands. The preparation contained $32 \times 10^{9}$ germs of B. pertussis $/ \mathrm{ml}, 50 \mathrm{Lf} / \mathrm{ml}$ of diphtheria toxoid and $25 \mathrm{Lf} / \mathrm{ml}$ of tetanus toxoid and will be called PDT-RI68. Combined vaccine PDT-368 was prepared by the Committee on Combined Vaccines (Chairman: Dr. S. Someya); it contained $11.5 \times 10^{9}$ germs $/ \mathrm{ml}, 60 \mathrm{Lf} / \mathrm{ml}$ of diphtheria toxoid and $20 \mathrm{Lf} / \mathrm{ml}$ of tetanus toxoid. Three dilutions of each specimen were injected once subcutaneously into guinea pigs. Ten animals were alloted for each dilution. Similar experiments were carried out simultaneously on the specimens diluted with GPB and with saline. The animals were challenged with $20 \mathrm{LD}_{50}$ of tetanus toxin 4 weeks after the immunization. The same batch of the toxin was used for the challenge in all laboratories throughout this experiment. The following scores were used for the calculation of the potency (Yamamoto et al., 1964): 
Symptom of the challenged animal

Score

Death within 2 days

0

Death after the 3rd day or survival with severe symptom 1

Survival with slight symptom 2

No symptom

4

TABLE I

Variation of potency ${ }^{1)}$ of tetanus component in combined vaccine PDT

\begin{tabular}{|c|c|c|c|c|c|c|}
\hline \multirow{3}{*}{$\begin{array}{l}\text { Labor- } \\
\text { atory }\end{array}$} & \multicolumn{4}{|c|}{ Potency of combined vaccine in international units ${ }^{2)}$} & \multirow{2}{*}{\multicolumn{2}{|c|}{$\begin{array}{l}\text { Potency of PDT-368 } \\
\text { relative to PDT-RI68 }\end{array}$}} \\
\hline & \multicolumn{2}{|c|}{ PDT-RI68 } & \multicolumn{2}{|c|}{ PDT-368 } & & \\
\hline & Saline & GPB & Saline & GPB & Saline & GPB \\
\hline I & $93(53-163)$ & $75(43-132)$ & $84(48-147)$ & $83(47-145)$ & $67(40-113)$ & $96(65-143)$ \\
\hline II-1 & $61(25-150)$ & $107(43-262)$ & $116(47-284)$ & $135(65-279)$ & N. D. & $125(42-372)$ \\
\hline II-2 & N. D. ${ }^{4)}$ & N. D. & $104(41-265)$ & $88(41-188)$ & N. D. & N. D. \\
\hline III & $167(117-230)$ & $131(91-190)$ & $194(139-272)$ & $250(172-361)$ & $116(83-146)$ & $154(106-233)$ \\
\hline IV & $44(20-97)$ & $21(10-47)$ & $39(18-88)$ & $57(30-107)$ & N. D. & $221(112-757)$ \\
\hline V-1 & $129(79-209)$ & $238(146-385)$ & $126(78-205)$ & $-353)$ & $89(63-127)$ & $92(54-156)$ \\
\hline $\mathrm{V}-2$ & $78(47-130)$ & $204(123-340)$ & $146(88-242)$ & $170(102-283)$ & $153(99-236)$ & $82(50-135)$ \\
\hline VI & $61(42-88)$ & $55(38-79)$ & $60(41-87)$ & $60(41-87)$ & $100(65-153)$ & $107(73-159)$ \\
\hline VII & $138(94-204)$ & $43(28-66)$ & $141(96-208)$ & $59(38-90)$ & $95(68-133)$ & $124(86-180)$ \\
\hline VIII & $39(18-86)$ & $130(66-256)$ & $24(11-53)$ & $110(56-217)$ & N. D. & $87(46-165)$ \\
\hline
\end{tabular}

Statistical analysis: (A) Including Standard Toxoid and two combined vaccines

\begin{tabular}{lrrrr}
\hline Nature of variation & \multicolumn{1}{c}{ SS } & DF & \multicolumn{1}{c}{ MS } & \multicolumn{1}{c}{ F } \\
\hline Parallelism & 21.1909 & 1 & 21.1909 & \multirow{2}{*}{$18.94^{* * 5)}$} \\
Error & 1361.4721 & 1217 & 1.1187 & \\
Total & 1382.6630 & & & \\
\hline (B) Including only combined vaccines & & & \\
\hline Parallelism & 0.1171 & 1 & 0.1171 & 0.1 \\
Error & 610.3450 & 551 & 1.1077 & \\
Total & 610.4621 & & & \\
\hline
\end{tabular}

1) Figures in parentheses show the fiducial limits of the potency at $P=0.05$

2) Determined as the relative potency to the National Standard Tetanus Toxoid (plain).

3) Calculated by taking the potency of RI 68 as 100 .

4) Not determined.

5) ** significant at $\mathrm{P}=0.01$.

6) Regression coefficient $\bar{b}=3.2408$ 
The results are summarized in Table I. The potency relative to the standard toxoid of each combined vaccines varied greatly, while the variation of relative potencies between two combined vaccines was small and most values were within the range of experimental error.

The effect of diluent on the potency of combined vaccine was not apparent in Table I except for Lab VII and Lab VIII, although the effects were quite different in the two laboratories. However, the repeated tests in NIH (Lab VII) showed that the result was reproducible. The potency of PDT-368 was always lower with the GPB diluent than with saline; 34, 49,53 and 59 with GPB and 319,100 and 141 with saline (see Fig. 1b). The change in the concentration of phosphate in GPB from $\mathrm{M} / 10$ to $\mathrm{M} / 60 \mathrm{did}$ not influence the results. It is difficult to explain why different effects of diluent on the potency were observed in NIH and Lab VIII. The source of the animal and the method of animal care may have had some influence. Further experiments are needed on these points. Table I also shows that parallelism of dose response lines was denied when all the data were combined, in contrast to the previous report (Murata et al., 1970) in which antitoxin titers of the immunized animals were compared. Such divergence of the slope of one type of toxoid from that of another type should be confirmed by further studies which involve both the antitoxin titration and the toxin challenge methods. However, the facts presented here indicate that the influences of various factors on the responses of guinea pigs to fluid tetanus toxoid and to combined vaccine are not similar and that the present standard toxoid (plain) is not suitable for the assay of toxoid component of the combined vaccine. Further experiments are needed to prepare the standard tetanus toxoid for the assay of combined vaccine and to choose an adequate procedure for the potency test.

\section{ACKNOWLEDGMENTS}

This work was carried out by the co-operation of the Association of the Bacteriological Products. We wish to express our gratitute to Dr. van Ramshorst of the Rijks Instituut for the generous gift of combined vaccine. We also thank Dr. M. Kurokawa and Dr. S. Ishida of the Department of General Biologics Control of the NIH, Tokyo, for their co-operation in the statistical analyses of the results and useful discussions.

\section{REFERENCES}

Murata, R., SOMEYA, S. AND KANEKo, J. (1970): Standardization of tetanus toxoid combined with pertussis vaccine. Japan. J. Med. Sci. Biol., 23, 211-216.

Yamamoto, A., AKama, K., Murata, R., Tsunehisa, Y. And Kaneko, J. (1964): Studies on the combined vaccine (Pertussis-Diphtheria-Tetanus). III. On the potency of tetanus toxoid determined by antibody and toxin challenge method. Japan. J. Bacteriol., 19, 207211 (text in Japanese).

\section{ANNEXE}

Participants of the Collaborative Studies

Chemo-Sero Therapeutic Research Institute The Kitasato Institute Saikin Kagaku Institute Co. Ltd.
H. KITAGAWA, Y. NISHIMURA, N. UENO

K. CHIBA, M. OISHI

K. TAMURA, T. SATO, K. IWATA 
Takeda Chemical Industries, Ltd.

S. SHUKUDA

Chiba Serum Institute

M. NIIRO, S. SUZUKI, S. SASAKI

Toshiba Institute of Biological Science

M. CHO, K. OISHIMA

Kan-onji Institute, The Research Foundation

for Microbial Diseases of Osaka University I. TSUNASHIMA, M. OGITA

The 2nd Department of Bacteriology

AKIO YAMAMOTO

National Institute of Health

SATORU KONDO

Shinagawa-ku, Tokyo 141, Japan

SEIJI SADAHIRO

RYOSUKE MURATA

(Received: July 18, 1972)

山本昭夫 ・近藤 了・貞弘省二・村田良介（国立予防衛生研究所 細菌第二部） 